\title{
Toleransi dalam Agama Hindu: Aplikasi Ajaran dan Praktiknya di Pura Jala Siddhi Amertha Sidoarjo
}

\author{
Achmad Zainul Arifin, Laila Qotrin Nada \\ Institut Pesantren KH. Abdul Chalim Mojokerto, UIN Sunan Ampel Surabaya \\ arifinzainul89@gmail.com, qotrinadaza@gmail.com
}

\begin{tabular}{|c|c|}
\hline \multicolumn{2}{|l|}{$\begin{array}{l}\text { Riwayat Jurnal } \\
\text { Artikel diterima: } \\
\text { Artikel direvisi: } \\
\text { Artikel disetujui: }\end{array}$} \\
\hline Kata Kunci: & Abstrak \\
\hline $\begin{array}{l}\text { Toleransi } \\
\text { Agama Hindu } \\
\text { Jala Sidhi Amertha }\end{array}$ & $\begin{array}{l}\text { Didalam artikel ini menjelaskan terkait toleransi yang ada di } \\
\text { ajaran agama Hindu, dari sisi konsep ajaran, teks-teks ataupun } \\
\text { slokanya, dan praktik maupun wujud pengaplikasiannya. } \\
\text { Kemudian, terkait konsep ajaran toleransi banyak sekali didalam } \\
\text { agama Hindu. Tapi, akan sedikit dipaparkan yang meliputi dari Tri } \\
\text { Hita Karana yang mengartikan tiga hubungan keseimbangan. } \\
\text { Lalu, ada Panca Sradha yang mengartikan lima keyakinan didalam } \\
\text { agama Hindu. Kemudian, Tat Twam Asih yang mengartikan suatu } \\
\text { ajaran tentang tata susila didalam agama Hindu. Lalu, ada Tri } \\
\text { Kaya Parisudha yang mengartikan tiga tingkah laku yang harus } \\
\text { disucikan, dan yang lain-lain. Salah satu sloka yang paling } \\
\text { terkenal dan menjadi pedoman dalam kehidupan berbangsa dan } \\
\text { bernegara yaitu Bhinneka Tunggal Ika tan hana dharma mangrwa, } \\
\text { yang dimana jika disimpulkan kita (seluruh umat beragama) } \\
\text { memiliki banyak cara untuk mencapai kesatuan. Penelitian ini } \\
\text { menggunakan metode kualitatif dengan melakukan wawancara } \\
\text { dan observasi secara langsung terhadap tokoh-tokoh agama Hindu } \\
\text { di Jawa Timur, selain itu penulis juga melakukan kajian pustaka } \\
\text { terhadap beragam rujukan agama Hindu. Penelitian ini } \\
\text { menghasilkan temuan bahwa, terdapat beragam kegiatan yang } \\
\text { dilakukan oleh umat Hindu di Pura Jala siddhi Amertha Juanda } \\
\text { yang mengandung toleransinya. Biasanya mereka melakukan } \\
\text { Bakti Sosial, Indonesia Merayakan Perbedaan yang mana dihadiri } \\
\text { oleh seluruh umat beragama, adalagi Semalam Nusantara Sidoarjo } \\
\text { merupakan kegiatan yang dihadari oleh beberapa etnis yang } \\
\text { berbeda. }\end{array}$ \\
\hline Keyword: & Abstract \\
\hline $\begin{array}{l}\text { Tolerance } \\
\text { Hinduism }\end{array}$ & $\begin{array}{l}\text { In this article, it explains the tolerance that exists in the teachings } \\
\text { of Hinduism, in terms of the concept of teachings, texts or } \\
\text { memorabilia, and practices and forms of application. Then, related }\end{array}$ \\
\hline
\end{tabular}




\begin{tabular}{|l|l|}
\hline Jala Sidhi Amertha & $\begin{array}{l}\text { to the concept of teaching tolerance is very much in Hinduism. } \\
\text { But, it will be explained a little which includes Tri Hita Karana } \\
\text { which defines three balance relations. Then, there is Panca Sradha } \\
\text { which means five beliefs in Hinduism. Then, Tat Twam Asih } \\
\text { which means a teaching about morality in Hinduism. Then, there } \\
\text { is Tri Kaya Parisudha which defines three behaviors that must be } \\
\text { sanctified, and others. One of the most well-known questions and } \\
\text { guidelines in the life of the nation and state is Bhinneka Tunggal } \\
\text { Ika tan hana dharma mangrwa, which if concluded we (all } \\
\text { religious people) have many ways to achieve unity. This study } \\
\text { uses a qualitative method by conducting interviews and direct } \\
\text { observation of Hindu religious figures in East Java, besides that } \\
\text { the author also conducts literature studies on various Hindu } \\
\text { religious references. This study found that there were a variety of } \\
\text { activities carried out by Hindus in the Amertha Juanda Pura Jala } \\
\text { siddhi containing tolerance. Usually they do Social Services, } \\
\text { Indonesia Celebrates the Difference which is attended by all } \\
\text { religious people, again Semalam Nusantara Sidoarjo is an activity } \\
\text { that is attended by several different ethnic groups. }\end{array}$ \\
\hline
\end{tabular}

\section{Pendahuluan (gunakan styles Satya Widya heading1)}

Negara Indonesia merupakan Negara luas yang ada di muka bumi ini (Andik Wahyun Muqoyyidin, 2013: 132). Yang mana manusianya memperlihatkan dari segi kehidupan yang bermacam-macam jenisnya.Seperti agama, suku, ras, budaya, dan masih banyak lagi (Muhammad Fahmi, 2018: 287). Banyak sekali suku-suku yang ada di Negara ini, bahkan budayanya juga.Negara ini juga dikatakan sebagai Negara yang sangat menjunjung tinggi terhadap bertoleransi.Karena dilihat sudah ada enam agama yang ada di Indonesia bahkan juga ada selain agama yang tinggal disini seperti penghayat kepercayaan, aliran sapto darmo, dan sebagainya.

Seorang insan dapat dikatakan sebagai orang sosial yang mana pasti akan memerlukan seseorang didalam kehidupannya (Toto Suryana, 2011: 127). Jikalau kita memerlukan orang lain maka antara kedua hubungan tersebut pasti akan menghasilkan dampak entah positif maupun negative (Art Semuel Thomas, 2018: 345). Untuk menjauhi dari dampak negatif maupun perselisihan maka harus ada usaha dalam bentuk toleransi.Yang dimana toleransi yaitu menghormati secara personal atau pribadi dan kelompok serta menjauhkan hal-hal yang berdampak buruk (Sabil Mokodenseho, Ismail Suardi Wekke, 2017: 68). Toleransi sepadan dengan semua agama yang dimana doktrin yang diberitahu untuk masyarakat biasanya tentang kasih sayang, cinta, kemanusiaan, kerukunan, maupun harmonisasi. 
Toleransi dibagi menjadi dua bagian yakni toleransi yang terbuka menerima perbedaan yang ada, ikhlas dari hati, serta hidup secara tentram dengan yang lain. Kemudian yang kedua toleransi yang memiliki keseimbangan yaitu diberikannya peluang untuk berpendapat bukan malah menjatuhkan serta mematikan pendapat tersebut.Ini diperlukan juga karena sejatinya toleransi itu ingin menggapai kerukunan, keseimbangan, serta keharmonisan antar umat beragama.

Menyikapi dalam bertoleransi yang mana suatu hal sangat dipentingkan untuk harmonisasi seluruh umat beraagama (I Ketut Tangga Parasmita, 2017: 249). Andaikan tidak adanya toleransi kemungkinan perselisihan antar umat agamalain pasti mudah terjadi. Maka dari itu toleransi sangat diperlukan dalam umat beragama.Sebenarnya, semua agama tidak ada yang mengajarkan adanya sebuah perselisihan karena memang tidak ada yang suka yang namanya dengan konflik maupun perselisihan.Perselisihan mungkin saja bisa terjadi yang mana perasaan seseorang tidak bisa terkendalikan. Ya bagaimanapun sebisa mungkin ada upaya agar tidak terjadi sebuah perselisihan tersebut.

Agama merupakan sesuatu keyakinan yang dipegang teguh oleh pemeluknya. Seperti Agama Hindu, yang menganut agama tersebut pastinya orang Hindu. Sama halnya juga dengan agama-agama yang lain. Didalam ajaran agama Hindu tidak ada yang mengatakan maupun mengajarkan bahwa manusia hanya mencintai seseorang yang ada dalam lingkupnya saja. Jadi, kita (umat Hindu) pasti mencintai serta sayangilah seluruh makhluk dan teksnya juga ada yang telah dirangkum menjadi satu serta bunyinya:

“Sa'atah protasca wibhuh prajasu.” Artinya:

"Tuhan terjalin dalam makhluk yang diciptakannya." (Kitab Yajur Veda 32. 8). Yang dimana maksud dari sloka tersebut adanya saling menyayangi serta mencintai satu sama lain dan tidak pernah memandang perbedaan umat agama yang lain dari segi apapun.

Bentuk nyata dari toleransi bagi umat Hindu di Pura Jala Siddhi Amertha Juanda sangat beragam sekali. Dari bentuk yang terbesar hingga terkecil pun ada yang mana tanpa kita sadari. Seperti saat kita membantu maupun menolong orang lain sudah termasuk toleransi, ketika mau bepergian kemudian bertegur sapa dengan yang lain serta menebar senyuman pada mereka itu juga termasuk toleransi, ketika ada teman kita lagi bersedih lalu kita memberikan kebahagiaan padanya hingga dia tidak bersedih lagi itu juga toleransi, dan masih banyak lagi.

Bentuk nyata toleransi umat Hindu yang terbesar ketika di Pura Jala Siddhi Amertha seperti halnya mereka (umat Hindu) sangat menerima dan terbuka untuk kunjungan-kunjungan 
dari sekolah TK hingga perkuliahan. Lalu, disana juga ada kegiatan Indonesia yang Merayakan Perbedaan dimana merupakan kegiatan yang sangat menjunjung tinggi terhadap kerukunan antar umat beragama. Menurut saya agama Hindu ini merupakan agama yang paling tinggi dalam bertoleransi. Karena dilihat dari sisi pengaplikasiannya saja sudah sangat terlihat dan saya akui yang paling bertoleransi ialah agama Hindu dibandingkan dengan agama lain.

\section{Pembahasan}

\section{Toleransi}

Banyak sekali pengertian mengenai toleransi.Adapun beberapa pengertian dari toleransi yang mana toleransi merupakan seseorang yang cinta rukun, damai, tentram terhadap orang lain, memberikan kebebasan untuk mengeluarkan pendapat, dan saling menghargai (I Ketut Sudarsana, GAP Yuni Arwani, 2018: 6). Ada juga pengetian toleransi yakni sebuah syarat yang mengenai segalanya untuk mengamalkan pancasila dengan cara sebaik-baiknya serta dapat berinteraksi baik dengan masyarakat Negara Indonesia (Agung Suharyanto, 2013: 199). Adapula toleransi merupakan adanya keselarasan dalam perbedaan (Adeng Muchtar Ghazali, 2013: 284).

Selain itu, toleransi merupakan suatu bentuk untuk bertahan dalam menghadapi cobaan serta menahan untuk tidak menghakimi agama, keyakinan, maupun penganut ibadah agama yang lain (Muhammad Yasir, 2014: 171). Kemudian, toleransi juga merupakan sebuah reaksi seseorang untuk mengikuti aturan yang mana dapat menghargai satu sama lain (Abu Bakar, 2015: 123). Segi pandang Poerwadarminta didalam Kamus Bahasa Indonesia toleransi diartikan sebagai suatu sikap yang saling menghormati terhadap keyakinan umat agama lain (W. J. S. Poewadarminta, 1982: 835). Toleransi berasal dari bahasa inggris tolerance yang mengartikan menghargai kepercayaan umat agama yang lain tanpa ada perjanjian-perjanjian apapun (Sahibi Naim, 1983: 60). Lalu, toleransi juga berasal dari bahasa arab yaitu tasamuh Khadijah Mohd Khambali, Mohd Herzali Mohd Haled, 2008: 82), yang artinya murah hati, baik, dan berhati ringan. Toleransi juga merupakan suatu bentuk yang bisa menerima pendapat orang lain, namun tidak harus mengorbankan pendapatnya sendiri melainkan bisa istiqomah terhadap pendapat yang diyakininya (Lely Nisvilyah, 2013: 284). Toleransi mengartikan yakni adanya keikhlasan dalam menyikapi suatu keragaman (Mahmud Arif, 2012: 5).

Ada juga pengertian toleransi menurut beberapa ahli yakni pandangan Michael Wazler toleransi dijadikan suatu niscaya dalam ruang pribadi maupun kelompok karena maksud dari toleransi untuk membangun hidup yang damai antar sesama dalam segi keragaman maupun 
keberagaman Muhammad Ridho Dinata, 2012: 88). Kemudian, Heiler memandang toleransi direalisasikan dalam tindakan serta dijadikan sebagai bentuk untuk menghadapi adanya keragaman agama (Muhammad Ridho Dinata, 2012: 88). Dari kacamata Djohan Efendi toleransi merupakan suatu bentuk yang saling menghargai keanekaragaman. Yang mana dari bentuk tersebut tidak hanya mengakui keberadaan beserta hak-hak yang lain, melainkan dapat terjun langsung terhadap usaha untuk memahami adanya keanekaragaman.

Dari sudut pandang Nurcholish Madjid toleransi yaitu membahas tentang permasalahan doktrin serta kewajiban untuk melakukan doktrin tersebut (Erlan Muliadi, 2012: 65). Yang dimana jika toleransi tersebut membuahkan hasil dalam mengelola atau menata pergaulan yang baik antar kelompok yang berbeda maka harus dijadikan sebagai manfaat dari perlakuan doktrin yang baik pula. Yang kemudian, suatu manfaat dilihat sebagai nilai sekunder.Sedangkan, nilai primernya dilihat dari doktrin itu sendiri. Yang mana dijadikan sebagai hal yang primer sekalipun toleransi tersebut hanya untuk pribadi maupun kelompok tersendiri sama halnya tidak akan membuahkan hasil yang baik (Erlan Muliadi, 2012: 65).

Ada dua macam pendapat terkait rancangan toleransi yang pertama toleransi negatif merupakan toleransi yang hanya menginginkan umat lain tidak dilarang untuk bertindak semaunya. Yang kedua toleransi positif dimana merupakan suatu toleransi yang tidak hanya itu melainkan mengutamakan sebuah pertolongan dan prosesnya (INIS dan Pusat Bahasa Indonesia dan Budaya UIN Syarif Hidayatillah Jakarta, 2003: 126-127).

Jadi, dari keseluruhan pengertian toleransi bila disimpulkan bahwasannya suatu sikap yang tidak menyimpang dari aturan maupun norma, yang mana dapat menghargai serta menghormati antar sesama.Namun, tidak lepas dari pendekatan dengan memberikan metode dialog maupun musyawarah untuk saling menghargai pendapat supaya tidak menimbulkan suatu permasalahan.

Melihat sudut pandang al-Qardhawi, beliau membagikan toleransi mempunyai tingkatan-tingkatan (Sukron Ma'mun, 2013: 1226). Yang pertama, dimulai derajat toleransi low yaitu dikasih peluang untuk umat agama memeluk sesuai keyakinannya. Yang kedua, derajat toleransi middle yaitu adanya peluang bagi umat agama lain untuk melaksanakan tugasnya sebagai pemeluk agama. Jadi, melakukan sesuai ajarannya serta meninggalkan yang tidak patut untuk dilakukan dalam ajarannya.Yang ketiga, derajat toleransi high yaitu tidak semena-mena menganggap sesuatu hal itu benar maupun salah terhadap doktrin keyakinan masing-masing. 
Selain membahas pengertian toleransi, akan dibahas bentuk-bentuk toleransi menurut Abdul Karim yang mana meliputi dua hal (Agung Suharyanto, 2013: 199) yaitu:

1. Toleransi Agama

Memberikan peluang terhadap pemeluk agama lain untuk beribadah sesuai keyakinannya.Jadi, seseorang harus diberikan kebebasan untuk meyakini maupun memeluk agamanya masing-masing tanpa ada paksaan.

\section{Toleransi Sosial}

Suatu bentuk yang tidak boleh keluar dari ketentuan atau aturan yang telah ditetapkan oleh Pancasila, UUD’45, serta yang telah diajarkan tiap masing-masing agama.

Oleh karena itu, toleransi agama dan sosial sangat dipentingkan untuk orang-orang yang beraneka ragam. Dari situlah kita harus memiliki upaya untuk tidak menyakiti satu sama lain, saling menghormati, serta tidak mengucilkan terhadap yang lain (Ika Fatmawati Faridah, 2013: 16).

Toleransi sama halnya dengan sikap positif yaitu saling menghargai dengan cara memberikan kebebasan HAM atau Hak Asasi Manusia. Sebenarnya, adanya hakekat toleransi ketika kita dapat hidup bersampingan secara damai, tentram, serta dapat menghargai antar keberagaman (Casram, 2016: 161). Maka dari situlah akan terealisasikan hubungan yang baik di kalangan umat beragama. Tujuan dari toleransi meliputi dari:

a. Terbentuknya unsur-unsur yang dapat menjamin terhadap keamanan personal

b. Harta benda, dan

c. Perangkat-perangkat minoritas atau jumlah yang lebih sedikit dibandingkan dengan lainnya dalam suatu kelompok (Casram, 2016: 191).

Jika dilihat dari perwujudan tujuan toleransi tersebut menghasilkan sebuah kehidupan yang aman, damai, tentram, menghormati maupun menghargai antar agama, serta dapat menerima pendapat antar sesama tanpa harus menghakimi satu sama lain.

\section{Teks Toleran dalam Agama Hindu}

Sebelum membahas teks-teks toleran yang ada dalam agama Hindu, akan dikupas terkait seperti apa konsep ajaran didalam agama Hindu. Karena yang dibahas toleransi, maka yang akan dibedah yakni konsep ajaran toleransi dalam agama Hindu. 
Yang mana adanya keterkaitan dengan toleransi yaitu sebuah lingkungan, jadi ada hubungan keseimbangan manusia kepada Tuhan atau disebut Parahyangan, hubungan manusia dengan manusia itu sendiri atau bisa disebut Pawongan, dan hubungan manusia dengan lingkungan atau yang disebut dengan Palemahan. Dari lingkungan ini, banyak orang-orang yang melihat serta menganggap salah arti terhadap umat Hindu. Banyak yang mengartikan sebuah lingkungan tersebut dijadikan sebagai pemujaan terhadap syetan, padahal tidak seperti itu. Bahkan umat Hindu menyadari bahwa keseimbangan manusia tersebut tidak bisa dilepaskan dari keseimbangan suatu alam. Jika suatu alam itu rusak, maka secara otomatis masyarakat yang hidup di muka bumi ini akan mendapatkan musibah atau kejadian yang terjadi dari alam yang rusak tadi. Oleh karena itu perlunya alam tersebut mendapatkan pelestarian dari masyarakatnya, yang kemudian dinamakan harmonisasi. Dari ketiga hubungan tersebut umat Hindu menyebutnya Tri Hita Karana (tiga hubungan keseimbangan) (Made Budiastika, 2018).

Kemudian, penyebab dari hubungan itu yaitu tadi yang telah dipaparkan sebelumnya.Nah, dari ketiga hubungan tersebut tidak bisa berdiri sendiri-sendiri yang dikarenakan kita tidak bisa menjalin sebuah hubungan yang baik dengan tuhan saja melainkan semua manusia serta alam merupakan suatu ciptaan tuhan. Menjaga harmonisasi manusia dengan manusia sama halnya kita menjaga keharmonisasian terhadap tuhan. Jika salah satunya ada yang tidak seimbang maka terhadap tuhan juga tidak ada yang seimbang. Contoh yang kecil saja ketika kita menyakiti orang lain yang dimana secara tidak langsung kita sudah menyakiti tuhan. Menyakiti manusia maupun merusak alam sama halnya kita juga menyakiti tuhan, karena pada dasarnya semuanya merupakan ciptaan dari tuhan beserta merupakan bentuk harmonisasi. Yang paling mendasar didalam agama Hindumereka sangat menjunjung tinggi terhadap harmonisasi yakni kepada sesama manusia, alam, maupun kepada tuhan itu adanya ajaran yang dinamakan Panca Sradha (Made Budiastika, 2018).

Di Panca Sradha ini bahwasannya umat Hindu meyakini lima keyakinanmeliputi yang pertama, mengakui adanya keberadaan beliau yang maha kuasa. Yang kedua, percaya adanya atman yang menjiwai serta memberikan hidup terhadap semua makhluk baik manusia, tumbuhan, hewan, maupun tuhan. Yang ketiga, percaya adanya karma phala, mungkin kalo di agama Islam bisa dinamakan sebuah amalan.Yang mana karma diartikan sebagai perbuatan sedangkan phala diartikan sebuah hasil.Jadi, karma phala merupakan hasil dari perbuatan yang kita lakukan (I Nyoman Prayudi Bintara, 2018). Bagaimana amalan tersebut? Jadi adanya baik dan buruknya suatu amalan itu akan kembali kepada kita. Nah, jika kita berbuat baik terhadap seseorang maka dari niscaya tersebut kita akan mendapatkan timbal baik juga walaupun tidak 
dari orang yang kita tolong. Mungkin saja yang membalas bisa dari tuhan, karena ya kita kembali pada dasarnya bahwa semua merupakan ciptaannya. Seperti halnya pada tempo dulu adanya peristiwa bom ketika di Bali, seluruh umat Hindu menyerahkan peristiwa tersebut kepada tuhan yang maha kuasa. Mensirnakan jiwa manusia itu pasti akan mendapatkan karma atapun amalan. Jadi, karma merupakan perbuatan baik buruknya seseorang yang mana ada hukumnya atau bisa disebut kausa prima yaitu hubungan sebab akibat. Dimana dia yang menjadikan sebuah akibat tertentu maka dia yang akan mendapatkan sebab dari akiat tersebut (Made Budiastika, 2018).

Semisal, ketika kita sudah lulus, wisuda, dan mendapatkan title maupun gelar sarjana agama (S.Ag) karena kita mengambil jurusan yang mengarah kesitu. Namun, lain lagi jika kita mengambil jurusan ke malang yang pastinya kita akan mendapatkan tiket yang jurusannya Surabaya ke Malang. Dan hal tersebut tidak bisa kita tempelkan untuk title di akhir nama kita. Jadi, yang berkaitan diluar dari adanya logika sebetulnya bisa dicontohkan ataupun diilustrasikan di kehidupan sehari-hari (Made Budiastika, 2018). Contoh lagi mengenai karma, disaat kita kelaparan, apa sih yang menyebabkan kita bisa lapar? Apakah sudah makan?Sudah.Tapi, mengapa masih lapar?Karna makannya sudah kemarin dan kita juga sudah mengeluarkan beberapa sisa makanan tersebut.Bagaimana biar kita tidak lapar?Ya kita harus makan kembali.Itu merupakan contoh yang paling kecil yang mana bisa dinalar dalam kehidupan sehari-hari. Apalagi jika kita hubungkan dengan sosial seperti, orang lain dicubit terasa sakit lalu, jika kita dicubit juga akan terasa sakit. Maka, jika kita dicubit terasa sakit jangan pernah mencubit orang lain. Itu juga termasuk hubungan sebab akibat. Adapun contoh yang lain ketika diperjalanan dalam posisi sedang amarah, kemudian melirik seseorang dengan tatapan yang sangat indah yang mana matanya merah serta keluarlah suatu ucapan khas Surabaya dan tidak berselang lama mulailah sebuah pertengkaran.

Mengapa adanya pertengkaran tersebut?Karena dari kita sendiri sudah mengirimkan sinyal kebencian terhadap mereka maka balasannya juga kebencian. Dari sinyal ini merupakan bentuk kedalam yang mana jika orang lain tidak suka karena dari kita sendiri juga tidak suka. Persemisalan, kita tidak suka jika ada barang kita yang dicuri maka jangan mencuri barang orang lain. Mencuri barang seseorang sesungguhnya merupakan bentuk bahwa kita sedang kehilangan. Kita melakukan perbuatan yang buruk terhadap seseorang sama halnya kita telah menghilangkan perbuatan baik yang ada dalam diri kita. Jadi, dengan berfikir seperti itu maka adanya ajaran yang namanya Tat Twam Asi (Made Budiastika, 2018). 
Yang mana jika kita tidak ingin diperlakukan tidak baik oleh orang lain maka kita tidak boleh juga memperlakukannya dengan tidak baik. Jadi, jika kita ingin diperlakukan baik oleh orang lain dan mereka juga suka terhadap kita maka perlakukanlah mereka dengan sebaik mungkin didalam suatu kehidupan sehari-hari. Tidak berarti apa yang kita miliki kita harus mengistimewakan mereka, paling tidak perilaku kita terhadap mereka, tidak menyakiti orang lain maka kemanapun kita pergi kita tidak akan disakiti oleh mereka. Andaikan kita melakukan keburukan dengan mencuri maka kita juga akan memiliki ke khawatiran apa yang barang kita curi sewaktu-waktu bisa menandai kita yang akhirnya kita merasa ketakutan dan dihantui. Bukan hanya mencuri melainkan melakukan hal-hal yang buruk hasil yang kita dapatkan pun juga sama. Dari situlah pasti ada akibatnya, jadi siapapun yang melakukan keburukan terhadap orang lain maka dia tidak bisa hidup tenang dan damai dalam kehidupannya. Yang kemudian juga bisa dikatakan dalam bentuk keseimbangan keharmonisan kita terhadap orang lain (Made Budiastika, 2018).

Contoh lain ketika kita berada di kampus UIN Sunan Ampel Surabaya yang mana ada syarat-syarat yang harus dipenuhi didalam kampus seperti diwajibkan memakai jilbab atau kerudung, kemudian sewaktu-waktu kita tidak memakai jilbab tersebut dan pastinya akan ada perasaan takut disuruh pulang, ditegur oleh dosen, atau apalah itu. Kenapa ada perasaan seperti itu?Karena kita sendiri tidak mematuhi maupun memenuhi syarat-syarat yang telah ditentukan oleh kampus tersebut.Lalu, adalagi termasuk pembayaran SPP, ketika dosen menjelaskan kemungkinan kitanya malah sibuk sendiri ada yang main handphone, ada yang nge-game, ada yang tidur, dan lain-lain (Made Budiastika, 2018).

Yang keempat, percaya adanya purnabawa atau samsara atau reinkarnasi artinya kelahiran yang berputar terus-menerus. Biasanya orang JawaHindu mengatakan jatma. Jadi, dasar yang tentang karma tadi, umat Hindu menjadi takut jikalau reinkarnasi ataupun purnabawa menjadi seseorang yang buruk. Niscaya seseorang seketika hidupnya selalu melakukan kejahatan, maka ketika dia di reinkarnasi jadilah seseorang yang jahat.Jahatnya seseorang tidak selalu menjadikannya seperti manusia, hewan ataupun binatang, bukan seperti itu melainkan bentuknya menjadi beraneka ragam.Seandainya seseorang itu menjadi manusia, maka jika dilihat dari segi wajahnya senyumnya bagaikan senyumnya serigala. Meskipun serigala itu tersenyum dimana-mana kita tidak akan mendekati serigala tersebut dan pastinya akan menajuh dari binatang tersebut. Beda lagi kalau senyumannya manusia pastinya terlihat manis dan indah untuk dipandang. Adapula ketika seseorang dengan tatapan mata yang mana orang tersebut lahir dengan membawa kejahatan, tatapan matanya juga sadis serta tajam, dan 
seolah-olah dia ingin menerkam, merampok, membunuh.Segala bentuk kejahatan yang dilakukannya dapat dilihat dari segi wajahnya, kemudian dari hidungnya yang mana adakala caranya ketika bernafasseakan-akan ingin melakukan kejahatan, lalu dari bentuk bibirnya yang mana dapat mencerminkan perbuatan yang ingin dilakukannya.Jadi, semua bentuk fisik kita tersebut dapat menunjukkan sifat-sifat kelahiran kita (Made Budiastika, 2018). Namun, jika adanya karma baik seseorang di masa lalu, mau dia asal berbicara saja sudah terlihat syahdu untuk didengar, dan lebih dari itu, walaupun bicaranya seseorang itu biasa saja tapi seakanakan berbicaranya seperti sedang membaca puisi, sedang bersenandung, dan membuat sekitarnya nyaman untuk berada di dekatanya. Mungkin saja seseorang tersebut bisa dirindukan karena teringat cara bicaranya yang sopan, halus, dan baik.

Sedangkan yang karmanya buruk di masa lalu, kita akan merasa takut. Yang kemudian, umat Hindu sebut sebagai kelahiran dari surga cyuta dan kelahiran dari neraka cyuta. Yang namanya surga cyuta merupakan kelahiran dengan membawa sifat-sifat surgawi, yang mana badannya sempurna, postur tubuh yang tinggi dengan besar badannya yang ideal, dipandang orang itu baik, didalam tubuhnya tidak ada kecacatan, dari segi wajah jika dilihat ada rasa ketertarikan, cuman bukan berarti ada rasa suka maupun senang yang berbeda melainkan ada rasa adem ayem jika berada didekatnya, meskipun seseorang itu terlihat kaya maupun miskin tapi dia tetap peduli terhadap lingkungan, tetap loyal terhadap kalangan bawah, kemudian ada orang yang susah namun dia memberikan kebahagiaan serta tanggap kepada orang tersebut dan tidak harus berupa materi yang diberikan kepadanya (Made Budiastika, 2018).

Selanjutnya, dia tidak semena-mena menyakiti binatang, tumbuhan, karena didalam Hindu juga diajarkan semacam adanya kewajiban bagaimana caranya untuk memelihara binatang serta tumbuhan tersebut. Maka dari itu hampir di tiap-tiap rumah yang beragama Hindu pasti memiliki halaman yang berisi kembang atau bunga, karena banyak orang yang suka dengan itu. Namun, yang lebih menarik lagi dari itu ialah bunga hati kita. Yang dimana ketika hati kita mendekati seseorang dengan penuh kesenangan maupun kegembiraan atau kerinduan maka akan menjadikan seseorang yang kita jumpai merasakan senang. Jadi, bukan hanya bunga yang tampak melainkan bunga yang tidak tampak pula menjadi inner beauty atau kecantikan dari dalam akan terpancar dari wajah kita, mata kita, mimik kita yang mencerminkan cara berbicara dengan seseorang (Made Budiastika, 2018).

Kebalikannya dari surga cyuta berarti neraka cyuta yang merupakan kelahiran dengan membawa sifat-sifat neraka, menakutkan, bagaikan burung pemakan bangkai. Andaikan kita bandingkan dengan burung merak perbedaannya sangat jauh sekali, yang mana burung 
pemakan bangkai dari bentuk kepalanya saja tidak ada bulunya, melihat dari postur tubuhnya juga tidak menarik, tidak ada warna-warni, burung ini dalam radius berapa kilopun sudah bisa merasakan bagaimana adanya kematian. Jadi, berbeda dengan burung yang terlihat menyenangkan, adanya warna-warni.Ada juga binatang yang melata seperti ular dan masih ada orang yang suka dari pada burung pemakan bangkai.

Beda lagi kalau ular dibandingkan dengan kucing, mata kucing bundar serta bisa membawa rasa senang sedangkan mata ular ada garisnya namun bawaannya tidak ada rasa suka mungkin kalau di Islam dapat dikatakan pembawaan dari iblis, jika dilihat diantara kedua mata tersebut mata yang tampak menakutkan yakni matanya ular yang mana semakin ditatap ular tersebut semakin besar. Dari situlah menjadi kekhawatiran didalam Hindu yang menyebabkan masyarakat Hindu itu takut untuk berbuat jahat.Takut untuk tidak dapat membina harmonisasi, takut untuk tidak bisa menjaga kerukunan, oleh karena itu dijaga sekali saja baik dalam perkataan, pemikiran, ataupun perbuatan akan menjadi dasar mengapa seseorang Hindu tersebut biasanya dalam berbuat, semisal pada tempo dulu ketika di Bali jika menaruh sepeda motor di pinggir rumah itu aman-aman saja dan jangan samakan dengan sekarang. Zaman sekarang sudah berubah, bukan hanya dari orang luar saja yang mana kepentingan tiap orang pasti berbeda, secara ekonomi banyak orang yang susah, mencari penghidupan saja sudah sulit apalagi secara tidak langsung biaya penghidupan juga tinggi, terkadang menjadi seseorang tersebut malah berpikir pendek, jikalau sudah memiliki pikiran yang tidak sehat maka dari segala sesuatu yang tampak memungkinkan akan dia kerjakan meskipun resikonya tinggi.Yang kemudian disebut sebagai Tri Kaya Parisudha (Made Budiastika, 2018).

Tri "tiga" Kaya "tingkah laku" Parisudha "yang harus disucikan". Jadi, tiga tingkah laku yang harus disucikan yang meliputi pertama, Manacika Parisudha artinya pikiran yang harus disucikan, kedua Wacika Parisudha artinya perkataan yang harus disucikan, ketiga Kayika Parisudha artinya perbuatan yang harus disucikan. Dari ketiga hal tersebut, mungkinkah kita masih berbuat anarkis terhadap orang lain? Pikirkanlah kembali. Jadi, sebelum melakukan hal tersebut mungkin kita akan berpikir sepuluh kali atau bisa beribu-ribu kali, jangan sampai memikirkan cara untuk membalas dendam kepada seseorang (Made Budiastika, 2018).

Contoh kecil saja disaat kita bertengkar dengan teman hanya masalah sepele lalu mengatakan "kamu ini kurang ajar sekali”, mungkin orang lain yang melihat sekaligus telah paham dengan peristiwa tersebut dia hanya akan diam dan tersenyum saja. Ibarat ketika kita melihat seorang bayi yang mana tingkahnya banyak, kadang-kadang ingin merampas barang 
karena ada yang disukainya padahal barang tersebut bukan miliknya, namun kita sebagai orang yang dewasa sebetulnya harus bisa menempatkan bagaimana cara membujuk si bayi tersebut kalau barang itu bukan miliknya atau kita membujuk orang lain itu untuk meminjamkan barangnya kepada si bayi. Nah, posisi orang dewasa yang bagaimana kita melihat sesuatu dengan hal yang positif.Seperti halnya niatnya hanya ingin bercanda, ketika ada seseorang mengatakan pada kita "huh, jangkrik kon". Kalau yang menerima dengan hal yang positif, kita anggap itu hanya sebuah candaan dan pastinya kita tidak akan marah karena hal tersebut. Tapi, kalau kita pikirnya negatif maka sesuatu yang tampak baik akan terlihat buruk (Made Budiastika, 2018).

Contoh lagi dalam hal politik atau hukuman dalam penjara atau di pengadilan yang mana seorang hakim maupun seorang pengacara akan melihat sesuatu dari sisi yang berbeda. Hakim akan mencoba melihat sesuatu secara objektif, sedangkan pengacara akan melihat dari seorang klien yang ditanganinya. Ketika klien tersebut salah, seorang pengacara akan mencari serta mengambil peluang yang mana menurutnya baik, biasanya pengacara juga akan melihat kliennya tidak memiliki kesalahan, berpikir positif bahwa dia akan menang. Dari situ Hindu berusaha selalu memandang seperti ke arah itu. Namun sama halnya dalam agama lain menyatakan sebagai hari kiamat yang mana mungkin sekarang ini masih dikatakan kiamat kecil seperti kematian, tapi kalau seperti pengahancuran itu sudah termasuk kiamat besar atau bisa disebut kiamat kubro. Didalam Hindu menyebutnya pralayang (Made Budiastika, 2018). Kami (umat Hindu) menginginkan serta berfikir dalam kiamat kecil ini yang bagaimana ketika mati bisa menjadi kematian yang khusnul khotimah yang ada di Islam, kalau di Hindu menginginkan mati dalam keadaan yang baik yang mana dalam ajaran karma ada tiga kematian yaitu salahpati (kematian ini kematian yang tidak ingin dicari tapi kita mendapat akibat tersebut seperti kecelakaan, mendapatkan musibah), ngulahpati (kematian yang dikarenakan kesalahan kita sendiri seperti bunuh diri, gantung diri), dan mati biasa (Made Budiastika, 2018). Dimana selain mati biasa itu merupakan kematian yang tidak benar atau tidak baik maupun kurang baik. Yang mana didalam Islam seperti kita mencari dalam keadaan yang khusnul khotimah tersebut. Istilahnya orang mati saja bisa mendapatkan ridhonya Allah SWT apalagi kalau kita melakukan dalam hal-hal yang baik pula.

Jadi, kami (umat Hindu) sama ingin melakukan yang sudah ditetapkan dalam ajaran Hindu yang mana sesuatu itu baik maupun buruk. Mengapa kita mengacu kearah sana? Ya karna ada dalam kitab suci salah satu bunyinya "Ri sakiwang sarwa bhuta, iking janma wwang juga wenang gumayana kening subha-subhakarma iking janma, kuneng akena ring 
subhakarna juga ikang asubha karna phalaning dadi wwang"(Kitab Sarasamuscaya sloka 2.) yang artinya "Hanya manusia saja yang mampu membedakan perbuatan baik dan buruk, oleh karena itu maka cepat-cepatlah berbuat baik". Yang kemudian, jikalau kita tidak mampu membedakan kedua perbuatan tersebut maka kita belum bisa dikatakan sebagai manusia melainkan dikatakan seperti binatang, tumbuhan, atau makhluk yang tak tampak yang mungkin di Islam disebut iblis maupun jin. Jadi, kita tidak tau bahwa kematian sama dekatnya dengan kehidupan yang mana mungkin saya masih belum pernah menyadari bahwa ketika menghirup nafas kita hidup namun ketika kita menghembuskan nafas kita mati. Jikalau kita menghirup serta menghembus nafas secara terus menerus berarti kita hidup mati.Tapi kalau menghembuskan nafas tidak kembali maka mati yang permanen atau biasanya orang mengatakan menghembuskan nafas yang terakhir.Terkadang kita juga tidak menyadari bahwa orang yang terlalu bahagia mendadak tersedak lalu mati yang mana meninggalnya dalam keadaan bahagia.Namun demikian sebaliknya mendengar berita yang kurang baik mendadak tersedak lalu mati.Jadi, kalau menghembuskan kita mati sebisa mungkin mengehembuslah dengan baik (Made Budiastika, 2018).

Contohnya seperti ini ada seseorang memanggil kyai yang sedang membenahi antena diatas genteng lalu seseorang itu mengatakan“kyai, putra jenengan main togel dan menang mendapatkan uang seratus juta" karena kesenangan yang berlebihan kyai tersebut lupa kalau berada di atas genteng yang kemudian jatuh dan meninggal. Nah, istilah kyai dalam Hindu bisa diganti dengan sebutan pemangku atau pandita. Jadi, seseorang ketika ingin berkata baik maupun buruk seharusnya intropeksi terlebih dahulu, dipikir dulu untuk kedepannya bisa membawa dampak yang baik atau buruk, sesuatu yang dilakukan dengan cara tidak baik maka menghasilkan yang tidak baik pula. Yang mana didalam Hindu jika melakukan perbuatan yang tidak bernafaskan dalam Kitab Weda maka hukumnya haram.

Yang kelima, percaya adanya Moksa. Yang mana jikalau perbuatan kita sudah sempurna maka tidak ada lahir kembali. Ini akan berkaitan dengan reinkarnasi I Gusti Ketut Budiartha, 2018).

Setelah membahas terkait konsep toleransi ataupun ajaran tentang toleran, banyak sekali pemaparan terkait contoh-contoh yang dapat dipahami yang selanjutnya akan dibahas tentang teks-teks tentang toleransi. Teks-teks toleransi didalam agama Hindu ini sistem belajar agama mungkin sedikit berbeda dengan agama Islam. Yang mana mungkin di Islamhampir semua teks bahkan ada yang bisa menghafal teks tersebut sedangkan di Hindu kalau menghafal teks iya tapi tidak semata-mata karena itu melainkan lebih spesifiknya merangkum dari teks- 
teks yang ada (I Gusti Ketut Budiartha, 2018). Seperti yang telah dipaparkan sebelumnya mengenai Panca Sradha, yang mana panca sradha ini bukan termasuk teks tapi merupakan suatu rangkuman dari filsafat yang ada dalam agama Hindu bahwasannya ada lima keyakinan yang dirangkum dari kitab suci karna jikalau dirangkum melewati teks itu terlalu panjang dan terlalu banyak maka dari itu diringkas serta dirangkum sedemikian rupa.

Kemudian adalagi Tri Kaya Parisudha, hal tersebut juga bukan dari teks melainkan dari suatu rangkuman isi kitab suci bahwasannya Hindu itu memiliki etika maupun susila dalam berkehidupan yang mana dalam berfikir baik, berbicara baik, serta berbuat baik. Teks tentang itu tidak ada tapi kumpulan dari ayat-ayat tersebut yang kemudian dirangkum menjadi satu dan hampir di seluruh umat Hindu seperti itu karena bukunya umat Hindu sangat banyak sekali hingga ada yang masih bingung saking banyaknya buku tersebut. Kalau di Hindu ada buku atau kitab suci Srhuti mungkin kalau di Islam bisa dikatakan al-Qur'an sedangkan kitab suci Smerthi atau Dharma Sastra mungkin kalau di Islam bisa disebut hadits. Smerthi ini didalam Hindu memiliki ratusan buku yang mungkin sulit sekali bagi kami (umat Hindu) untuk menghafalkannya maka dari itu kami (umat Hindu) menggunakan sistem resume atau rangkuman namun tidak meninggalkan teks-teks yang penting dalam ajaran kami dan tentunya kami akan tetap mempelajarinya (I Gusti Ketut Budiartha, 2018).

Namun, di Hindu juga ada teks mengenai toleransi yang mana kita (umat Hindu) menggunakan Smerthi yang hingga sekarang tetap terkenalpertamayaitu Bhinneka Tunggal Ika merupakan kitab karangan Mpu Tantular. Disitu kami (umat Hindu) mengakategorikan sebagai ayat toleransi yang paling terbesar, bunyinya:

"Hyang Buddha tanpahi Civa rajadeva, Rwaneka dhatu vinuvus vara Buddha Visva, Bhimukti rakva ring apan kena parvvanosen, Mangka ng Jinatva kalavan Civatatva tunggal, Bhinneka Tunggal Ika tan hana dharma mangrwa." Artinya:

"Hyang Buddha tiada berbeda dengan Syiwa Mahadewa, Keduanya itu merupakan sesuatu yang satu, Tiada mungkin memisahkan satu dengan yang lainnya, Karena hyang agama Buddha dan hyang agama Syiwa sesungguhnya tunggal, Keduanya memang hanya satu tiada dharma (hukum) yang mendua (Kitab Sutasoma, Pupuh ke 139 bait ke V).” Maksudnya dijadikan sebagai jalan atau cara namun tujuannya tetap satu serta letaknya di Burung Garuda Republik Indonesia.Kedua, ada Tat Twam Asih salah satu ayatnya yang berbunyi:

"Tatvamasyadivakyena svatma hi pratipaditah, neti neti srutirbruyadanrtam pancabhautikam.” Artinya: 
"Kamu adalah aku, Aku adalah Kamu" (Kitab Awadhutagita. 1. 25). Yang mana jika menyakiti kamu sama saja menyakiti diri sendiri. Ayat tersebut menjadi sebuah slogannya Hindu agar mudah diingat.Ketiga, ada yang namanya Wasudewa Kutumbakam merupakan istilah yang gampang diingat bahwasannya kita semua ini adalah bersaudara. Ada sebuah catatan didalam Hindu mengajarkan jangan terlalu tertarik dengan sebuah teks yang mana sebuah istilah-istilah tersebut jangan lupa disosialisasikan (I Gusti Ketut Budiartha, 2018).

Yang keempat, adapun tentang Tri Hita Karana, jadi maksudnya seperti ini beragama bukan hanya untuk tuhan melainkan harus seimbang. Vertikal keatas oke, vertikal kebawah juga oke yang mana menjaga lingkungan. Nah dari semua ini banyak kali orang yang mengatakan kalau kita (umat Hindu) menyembah syaitan. Padahal tidak, disini kami (umat Hindu) sayang terhadap binatang maupun tumbuhan, maka kami akan memuja alam tersebut. Memuja alam atau lingkungan sama halnya memuja kepada tuhan karena dasarnya juga merupakan ciptaannya tuhan. Tapi tidak hanya itu, horizontal juga diperlukan yaitu sayang terhadap sesama manusia jauh lebih penting, dunia akan terasa damai jika horizontalnya dilakukan dengan baik (I Gusti Ketut Budiartha, 2018).

Contohnya hotel di Bali dengan hotel di Jawa khasnya terlihat sekali. Kalau hotel di Bali memiliki luas 100 meter, lalu separuh dari itu akan diisi oleh tumbuhan-tumbuhan sehingga di Bali terlihat indah dengan kehijauannya dan banyak pengunjung maupun umat Hindu sendiri sering kesana.Termasuk Tri Hita Karana tadi yaitu Palemahan atau terhadap lingkungan.Beda dengan hotel yang di Jawa hanya sedikit yang ditanami tumbuhan mungkin tanah disini tanah yang berharga tidak seperti di Bali. Karena pikir mereka kalau ditanami tumbuhan tidak akan menghasilkan uang. Itulah merupakan realisasi dari Tri Hita Karana. Kami (umat Hindu) pun memiliki satu budaya di Hindu yang mewajibkan jikalau ada rumah yang luasnya hanya 10x10 meter tidak boleh diisi full bangunan, melainkan harus ada seperempat maupun separuh luas tersebut ditanami oleh tumbuhan (I Gusti Ketut Budiartha, 2018).

Yang kelima ada Catur Paramitha merupakan empat perilaku mulya yang terdiri dari maîtri yaitu mengembangkan sikap kasih sayang antar sesama, mudita yaitu berperilaku dengan upaya membuat orang lain senang dan bersimpati, karuna atau bisa disebut karunia yaitu suka menolong antar sesama, upeksa yaitu menjaga kerukunan, keselarasan, dan keseimbangan. Yang terakhir itu merupakan sesuatu yang sangat trend atau terbaru yang mana kita antar sesama harus bisa menjaga keharmonisan sebaik mungkin (I Gusti Ketut Budiartha, 2018). 
Ada tambahan lagi tentang Panca Satya yang merupakan lima kesetiaan dalam bertoleransi, apalagi kalau di Suku Tengger sangat terkenal mengenai hal tersebut. Satu Satya Samaya yakni setia kepada janji, Dua Satya Herdaya yakni setia kepada kata hati merupakan hal yang paling penting.Semisal, ada berita yang hoax dan kita mengetahui hal tersebut lalu di berita tadi adanya prabowo yang mana kita sangat bersimpati padanya, karena seperti itu yang sebenarnya kita menganggap berita tadi hoax menjadi tidak hoax dan meneruskan pemberitaan kepada khalayak umumnya.Kalo seperti ini bukan mengikuti kata hati tapi kita sudah dipengaruhi oleh partai, untuk menghindari dari kata hoax jangan sampai terpengaruh oleh semacam yang berbau politik, warna kulit, dan sebagainya.Tiga Satya Mitra merupakan setia dalam persahabatan. Contoh kecilnya saja jika sudah bersahabat jangan saling berbohong, seperti tina memiliki pacar yang bernama toni kemudian sahabat tina yang bernama leni malah menikung sahabatnya sendiri yang mana leni selingkuh dengan toni (I Gusti Ketut Budiartha, 2018). Empat Satya Wajana yaitu setia kepada apa yang kita bicarakan. Contohnya, Budi berkata "aku harus pergi ke les privat" tapi dia tidak berangkat. Sama saja dia tidak setia pada apa yang dia omongkan, hanya berbicara saja tapi tidak bertindak. Terakhir Satya Laksana merupakan setia kepada perbuatan. Yang mana kita harus bertanggung jawab apa yang telah kita perbuat dan jangan melemparkan ke orang lain yang sebenarnya ialah tanggung jawab kita. Adapun teks-teks toleransi yang mana juga merupakan dari kitab suci smerthi maupun sruthi dari bahasa Sansekerta salah satu bunyinya:

"Advesta sarva-bhutanam, maitrah karuna eva ca, nirmamo nirahamkarah, sama- dukhaksami." Artinya:

"Dia yang tidak membenci segala makhluk, bersahabat, cinta kasih dan bebas dari keakuan dan keangkuhan, sama dalam suka dan duka, pemberi maaf maka mereka akan mencapai kesempurnaan.”(Kitab Bhagawad Gita XII. 13). Ini juga merupakan rangkuman dari beberapa teks.

Adalagi teks-teks toleransi yang berasal dari bahasa Jawa Kuno, bunyinya:

"Prihen temen dharma dumeranang sarat, Saraga Sang Sadhu sireka tutana, Tan harta tan kama pidonya tan yasa, Ya sakti Sang Sajjana dharma raksaka.” Artinya:

"Manusia hendaknya senantiasa berhubungan baik dengan alam lingkungannya dengan maksud untuk melestarikannya demi tercapainya kesejahteraan dan kedamaian dalam kehidupan sehari-hari agar dapat mewujudkan kebahagiaan di dunia maupun di akhirat kemudian hari."(Kitab Ramayana: 24. 81). Ini merupakan cerita dari Ramayana. 
Adapula teks toleransi yang lain yang mana bunyinya:

"Sahrdayam sammanasyam, avidvesam krnomi vah, anyo anyam abhi haryata, vatsam jatam ivighnya." Artinya:

"Wahai umat manusia, Aku memberimu sifat-sifat ketulusan, keikhlasan, mentalitas yang sama dan perasaan berkawan tanpa kebencian (permusuhan). Seperti halnya induk sapi mencintai anak-anaknya yang baru lahir, begitulah seharusnya kalian saling mencintai satu sama yang lain (Kitab Atharva Veda III. 30. 1).” Merupakan tentang cinta kasih tanpa permusuhan.

Kemudian, ada contoh teks lain yang menunjukkan toleransi, bunyinya berasal dari bahasa Sansekerta:

"Samo 'ham sarvabhutesa, na medewsyo 'sti na priyah, ye bhajanti tu mam bhaktya, mayite besu ca 'pyaham.” Artinya:

“Aku tidak pernah pilih kasih dan selalu bersikap adil terhadap semua makhluk, bagiKu tidak ada yang paling Aku benci dan yang paling Aku kasihi.Mereka yang berbakti kepada $\mathrm{Ku}$, yang selalu memuja Ku, Aku akan selalu bersamanya.” (Kitab Bhagawad Gita IX. 29). Selain itu, adalagi teks toleransi juga berasal dari bahasa Jawa Kuno bunyinya seperti ini: "Yo yo yam yam tanum bhaktah sraddhayarcitumicchati, tasya tasyacalam sraddham tameva vidadhamyaham." Artinya:

"Kepercayaan apapun yang ingin dipeluk seseorang, Aku perlakukan mereka sama dan $\mathrm{Ku}-$ berikan berkah yang setimpal supaya ia lebih mantap.” (Kitab Bhagavad Gita VII. 21).

Kemudian ada teks yang lain yang berbunyi:

"Janam bibhrati bahudha vivacasam, nanadharmanam prthivi yathaukasam, sahasram dhara dravinasya me duham, dhruveva dhenur anapasphuranti." Artinya:

"Semua orang berbicara dengan bahasa yang berbeda-beda, dan memeluk Agama (kepercayaan) yang berbeda-beda, Sehingga Bumi Pertiwi bagaikan sebuah keluarga yang memikul beban. Semoga Ia melimpahkan kemakmuran kepada kita dan menumbuhkan penghormatan diantara kita, seperti seekor sapi betina kepada anak-anaknya." (Kitab Atharva Veda XII. I. 45).

Lalu ada teks lain yang bunyinya:

“Ghrtat Svadiyo madhunas 'cavovata.” Artinya: 
"Wahai umat manusia, berbicaralah dengan kata-kata yang lebih manis dari pada mentega dan madu yang dijernihkan.”( Kitab Reg Veda. III. 24. 20) Maksudnya ialah kita harus selalu bisa berbicara yang baik dan menyenangkan, jikalau kita bisa menyenangkan orang lain maka kita akan mendapatkan pahala. Tek tersebut masuk toleransi karena identik dengan ajaran Tri Kaya Parisudha yang lebih spesifiknya ke bagian Wacika yaitu berbicara yang baik.

Adapula teks lain yang berbunyi:

"Saknoti 'hai wa yah sodhum, prak sarira wimoksanat, kamakrodhabhawam wegam, sa yuktah sa sukhi "narah." Artinya:

"Dia yang dapat menahan nafsu birahi dan amarah didunia ini, sebelum meninggalkan jasad raganya, dia adalah Yogi, dia adalah orang yang bahagia.”(Kitab Bhagavad Gita V. 23) Yang mana dalam ajaran Hindu mengenai tentang pengendalian diri, kurangi yang berbau duniawi, dan perbanyaklah amalan rohani seperti mengendalikan nafsu birahi serta nafsu amarah. Jadi, ketika menjelangnya ajal pikirlah yang terkait spiritual yang dapat membawa amalan kita bukannya memikirkan tentang hal yang duniawi.Yoga merupakan kegiatannya sedangkan yogi orang yang melakukan kegiatan tersebut.

Dan masih banyak lagi terkait teks-teks yang mengandung ketoleransian.

\section{Praktik Toleransi di Pura Jala Siddhi Amertha}

Sebelum membahas praktik toeransinya, akan sedikit dijelaskan tentang Pura Jala Siddhi Amertha di Juanda. Pura Jala Siddhi ini merupakan tempat peribadatannya umat Hindu biasanya bagian kawasan Surabaya hingga sidoarjo dan sekitarnya. Lalu, pura ini diresmikan pada tanggal 23 Juni 2009 oleh bapak Kasal Laksamana TNI Tedjo Edhy Purdijatno. (I Gede Putu Suardana, 2018).

Selanjutnya akan dibahas terkait wujud nyata atau aplikasi toleransi umat Hindu yang ada di Pura Jala Siddhi Amertha Juanda yang meliputi dari:

\section{a. BAKSOS}

Biasanya kami (umat Hindu) sering melakukan hal tersebut guna mempererat tali kerukunan antar sesama (Made Budiastika, 2018).

b. Berkaitan dengan kesehatan massal.

c. Menerima kunjungan dari sekolah-sekolah. Biasanya dari TK Islam, Ponorogo, kemaren juga sempat kedatangan dari mahasiswa UIN Sunan Ampel Surabaya, ada 
juga dari beberapa mahasiswa UNESA. Sama halnya yang dibahas terkait harmonisasi toleransi (I Gusti Ketut Budiartha, 2018).

d. Aktif dalam organisasi FKUB yaitu Forum Kerukunan Umat Beragama. Jadi, apa saja program-program yang dikeluarkan dari organisasi tersebut kami (umat Hindu) selalu berusaha untuk serta merta hadir dan mengikutinya. Sebagian ada yang di bagian Provinsi, sebagian pula ada yang di bagian Kabupaten.

e. Kami (umat Hindu) menghimpun beberapa dana untuk berbagi takjil kepada umat muslim ketika memasuki di bulan Romadhon. Kemudian, kami juga pernah membantu korban yang sedang terkena bencana ataupun musibah. Ibaratnya sama seperti FKUB yang selalu siap siaga bila ada yang memerlukan bantuan (Made Budiastika, 2018).

f. Melaksanakan kegiatan bersama-sama dengan pendopo Sidoarjo yaitu Dharma Shanti merupakan kegiatan yang berkaitan dengan kedamaian. Biasanya kami dengan Agama Buddha kemudian didukung oleh Pemda yang dapat dipinjami tempat.

g. Adanya IMP atau bisa disebut Indonesia Merayakan Perbedaan. Kegiatan yang paling besar dan merangkul semua agama seperti Khatolik, Islam, Protestan, Buddha, Penghayat kepercayaan, Aliran Sapto Darmo juga ada. Dalam rangka toleransi serta kerukunan umat beragama (Made Budiastika, 2018).

h. Kegiatan SNS atau kegiatan Semalam Nusantara Sidoarjo. Kegiatan tersebut merupakan kegiatan lintas dari berbagai etnis. Dari etnis Bali yang diwakili oleh Hindu, etnis Manado biasanya diwakili oleh tionghoa, etnis Arab diwakili oleh Islam, etnis Maluku diwakili oleh agama Kristen. Yang dibahaspun sama halnya tentang kerukunan umat beragama.

i. Adapula yang menyangkut mengenai keagamaan, ketika ada perayaan hari raya suci Nyepi biasanya kami (umat Hindu) mengadakan kegiatan yang berkaitan adanya harmonisasian yaitu donor darah. Yang mana dalam rangka wujud harmonisasi kemanusiaan.

j. Adanya kegiatan jalan sehat yang dilakukan oleh lintas iman. 


\section{Kesimpulan}

Mendengar kata toleransi sudah tidak asing lagi di telinga kita. Toleransi tidak harus dengan sesama agamanya melainkan harus dengan agama yang lain. Yang mana toleransi bukan hanya diketahui dalam arti tapi harus ada bukti nyata kalau kita bertoleransi.Sebuah toleransi yaitu adanya bentuk saling menghargai antar umat beragama dan memberikan peluang kepada mereka untuk menyampaikan aspirasi maupun pendapat.

Teks-teks toleransi banyak sekali didalam ajaran agama Hindu yang kemudian dirangkum maupun diresume menjadi satu dari beberapa kitab atau buku. Salah satunya ada di Tat Twam Asih yang dimana merupakan bentuk untuk tidak menyakiti orang lain. Jadi, kita harus saling mengasihi, mencintai, maupun menyayangi satu sama lain. Yang mana kitabnya umat Hindu yaitu Kitab Shruti merupakan wahyu yang berasal dari tuhan dan diyakini sampai sekarang. Sedangkan Kitab Smerthi merupakan sebuah hasil ajaran yang berasal dari kitab srhuti.

Praktik ataupun wujud nyata dalam bertoleransi di Pura Jala siddhi Amertha banyak sekali yang dilakukan oleh umat Hindu disana. Dalam praktik tersebut umat Hindu bukan semata-mata hanya untuk pamer kepada publik melainkan merangkul seluruh umat beragama untuk mencapai suatu kedamaian, harmonisasi, serta kerukunan antar umat beragama agar tidak adanya sebuah perselisihan maupun perdebatan yang membawa dampak buruk.

\section{Daftar Pustaka}

Arif, Mahmud. (2012). "Pendidikan Agama Islam Inklusif-Multikultural”, Jurnal Pendidikan Islam, No. 1, Vol. 1.

Bakar, Abu. (2015). "Konsep Toleransi Dan Kebebasan Beragama”, Toleransi, Jurnal Media Komunikasi Umat Beragama, No. 2, Vol. 7.

Casram. (2016). "Membangun Sikap Toleransi Beragama Dalam Masyarakat Plural", Wawasan, Jurnal Ilmiah Agama dan Sosial Budaya, No. 2, Vo. 1.

Dinata, Muhammad Ridho. (2012). “Konsep Toleransi Beragama Dalam Tafsir Al-Qur'an Tematik Karya Tim Departemen Agama Republik Indonesia”, ESENSIA, Jurnal Ilmuilmu Ushuluddin, No. 1, Vol. XIII.

Fahmi, Muhammad. (2018). "Pura di Tanah Wali: Kontribusi Riil Toleransi Islam Indonesia bagi Peradaban Dunia, Jurnal Annual Conference for Muslim Scholars, Seri 1.

Faridah, Ika Fatmawati. (2013). "Toleransi AntarUmat Beragama Masyarakat Perumahan", Jurnal Komunitas, No. 1, Vol. 5. 
Ghazali, Adeng Muchtar. (2013). "Teologi Kerukunan Beragama Dalam Islam: Studi Kasus Kerukunan Beragama di Indonesia”, Analisis, Jurnal Studi KeIslaman, No. 2, Vol. XIII.

INIS dan Pusat Bahasa Indonesia dan Budaya UIN Syarif Hidayatillah, (2003). Konflik Komunal di Indonesia saat ini. Jakarta: INIS.

Khambali, Khadijah Mohd dan Mohd Herzali Mohd Haled. (2008). "Toleransi Beragama Dan Amalannya Di Malaysia: Rujukan Kepada Artikel 11 Perlembagaan Persekutuan Malaysia", Jurnal Ushuluddin, Vol. 27.

Kitab Atharva Veda III. 30. 1.

Kitab Atharva Veda XII. I. 45.

Kitab Awadhutagita. 1. 25.

Kitab Bhagavad Gita V. 23.

Kitab Bhagavad Gita VII. 21.

Kitab Bhagawad Gita IX. 29.

Kitab Bhagavad Gita XII. 13.

Kitab Ramayana: 24. 81.

Kitab Reg Veda. III. 24. 20.

Kitab Sarasamuscaya sloka 2.

Kitab Sutasoma, Pupuh ke 139 bait ke V.

Kitab Yajur Veda 32. 8.

Ma'mun, Sukron. (2013). "Pluralisme Agama dan Toleransi dalam Islam Perspektif Yusuf alQardhawi”, Jurnal Humaniora, No. 2, Vol. 4.

Mokodenseho, Sabil dan Ismail Suardi Wekke. (2017). "Toleransi Beragama dan Pembelajaran Agama Islam: Harmoni Masyarakat Minoritas Muslim Manado”, Jurnal Prosiding, No. 1, Vol. 1.

Muliadi, Erlan. (2012). "Urgensi Pembelajaran Pendidikan Agama Islam Berbasis Multikultural di Sekolah”, Jurnal Pendidikan Islam, No. 1, Vol. 1.

Muqoyyidin, Andik Wahyun. (2013). “Membangun Kesadaran Inklusif-Multikultural untuk Deradikalisasi Pendidikan Islam, Jurnal Pendidikan Islam, No. 1, Vol. II.

Naim, Sahibi. (1983).Toleransi dalam Pergaulan Antar Umat Beragama. Jakarta: Gunung Agung. 
Nisvilyah, Lely. (2013). "Toleransi AntarUmat Beragama Dalam Memperkokoh Persatuan Dan Kesatuan Bangsa: Studi Kasus Umat Islam Dan Kristen Dusun Segaran Kecamatan Dlanggu Kabupaten Mojokerto, Kajian Moral dan Kewarganegaraan, Jurnal Mahasiswa UNESA, No. 1, Vol. 2.

Parasmita, I Ketut Tangga. (2017). "Toleransi Umat Beragama antara Hindu dan Islam di Kelurahan Lelateng Kecamatan Negara Kabupaten Jembrana, Jurnal Penelitian Agama Hindu, No. 2, Vol. 1.

Poewadarminta, W. J. S. (1982). Kamus Umum Bahasa Indonesia. Jakarta: Balai Pustaka.

Sudarsana, I Ketut dan GAP Yuni Arwani. (2018). "Internalisasi Pendidikan Karakter Melalui Pelaksanaan Dharmagita Pada Sekaa Taruna”, Jurna Ilmu Agama, No. 1, Vol. 1.

Suharyanto, Agung. (2013). "Peranan Pendidikan Kewaranegaraan Dalam Membina Sikap Toleransi Antar Siswa”, Jurnal Ilmu Pemerintahan dan Sosial Politik UMA, No. 2, Vol. 1.

Suryana, Toto. (2011). "Konsep dan Aktualisasi Kerukunan Antar Umat Beragama”, Jurnal Pendidikan Agama Islam, No. 2, Vol. 9.

Thomas, Art Semuel. (2018). "Penggunaan Saluran Komunikasi dalam Menjaga Sikap Hidup Toleransi Beragama di Desa Kema satu Kabupaten Minahasa Utara, Jurnal al-Qalam, No. 2, Vol. 24.

Yasir, Muhammad. (2014). “Makna Toleransi Dalam Al-Qur’an”, Jurnal Ushuluddin, No. 2, Vol. XXII.

\section{Informan Data:}

Made Budiastika., S.Ag Selaku Pembimas Sidoarjo.

I Gusti Ketut Budiartha., S.Ag. MPdH. Selaku Sekjen PHDI Jatim.

I Nyoman Prayudi Bintara Selaku Ketua Pemuda Hindu Jatim.

I Gede Putu Suardana Selaku Seksi Rohani di Pura JSA. 